\title{
Disarming the xenophobic everyday: Muslim migrants and the horizons of urban mutuality in Durban
}

\author{
Benjamin Kirby, Francis Sibanda and Fred Charway
}

\section{Introduction}

This article explores the everyday lives that African migrants share with other residents in Durban, KwaZulu-Natal. ${ }^{1}$ Drawing on fieldwork conducted at a time of heightened xenophobic mobilization in South Africa, we explore how mundane rituals of social interaction have become key sites of contestation about who can participate in the urban everyday. We demonstrate that Muslim forms of sociality enable some African migrants to navigate this highly politicized landscape of belonging, generating unexpected forms of reciprocity that sustain the very fabric of the city itself as a shared habitat. In doing so, we contribute to three interdisciplinary research agendas in African studies. The first of these theorizes the quotidian lives of African cities as sites of implicit 'mutuality', even in settings characterized by social division and insecurity (Bjarnesen and Utas 2018; Chari and Gillespie 2014; Hansen and Verkaaik 2009; Larkin 2016; Teppo 2015). The second delves into the micro-politics of everyday interaction that migrant populations negotiate in different African cities (Charway 2019; Dube 2017; Hankela 2020; Sheridan 2018; Sibanda and Sibanda 2014; Siziba 2016; Vinckel 2015). The third examines the importance of religious forms of sociality among migrant populations in South African cities exposed to xenophobic violence (Alhourani 2015; Bukasa 2018; Kaarsholm 2012; Landau 2009; Sadouni 2014; Vawda 2017).

We take as our point of departure a recent article by Obvious Katsaura (2018:4) that explores the possibility of 'multinational coexistence' in Johannesburg, a city 'haunted' by 'everyday and episodic violence' against African and Asian migrants. Katsaura (ibid.: 6) provides a compelling account of 'ethno-mutualism'

\footnotetext{
Benjamin Kirby is British Academy Postdoctoral Research Fellow at the Centre for African Studies (LUCAS), University of Leeds. Email: b.j.kirby@leeds.ac.uk

Francis Sibanda is a Postdoctoral Research Fellow at the Centre for Leadership Ethics in Africa (CLEA), University of Fort Hare. Email: fsibanda@ufh.ac.za

Fred William Charway recently completed his $\mathrm{PhD}$ at Fort Hare Institute of Social and Economic Research (FHISER), University of Fort Hare. Email: fcharway@ufh.ac.za

${ }^{1}$ For the purposes of this article, we use the term 'migrants' in place of 'foreign nationals', which has widespread currency in South Africa. We also use the term 'African migrants' to denote those who came to South Africa from other African countries. Where our interlocutors frequently made reference to 'locals', we use this term with quotation marks, generally preferring to use 'black South Africans' in its place. We use the term 'Indian South Africans' and 'white South Africans' to describe residents of Indian and European descent respectively. Finally, we use the term 'residents' to denote all those individuals (of whatever ethnic or national identity) who are routinely present in the Central Business District (CBD), incorporating both those who inhabit properties as well as business operators.
}

(C) The Author(s), 2021. Published by Cambridge University Press. This is an Open Access article, distributed under the terms of the Creative Commons Attribution licence (http://creativecommons.org/ licenses/by/4.0/), which permits unrestricted re-use, distribution, and reproduction in any medium, provided 
in the city, demonstrating that residents 'have no choice but to indulge ethnonational boundary crossing' on an everyday basis. This is because residents, by virtue of the fact that they inhabit the same urban ecology, are obliged to attune themselves to shared 'routines, rituals, and rhythms' which organize everyday life in Johannesburg. In other words, people's lifeworlds are built with and around one another through tacit modes of togetherness. While the 'immediacies' that emerge between residents rarely entail 'thick' bonds of social trust, Katsaura observes that even short-lived interactions fundamentally rely on a level of mutual 'recognition' and cooperation between participants (see also Hankela 2020). It is precisely in these moments of co-presence that Katsaura locates an 'ethnonational mutualism' which permeates Johannesburg's urban everyday.

In this article, we use our research in Durban to both complicate and extend Katsaura's analysis. Our discussion draws on fieldwork conducted in the city's Central Business District (CBD) and the adjoining Warwick Junction Precinct, together colloquially known as 'town'. We focus on the subdivision of the CBD known as the Grey Street Complex, also called the 'Indian Quarter' because it has served as a commercial and cultural centre for Indian South African residents since the late nineteenth century (Desai and Vahed 2011; Kumar 2019; Rosenberg 2012; Soske 2017). While the CBD has experienced an overall drop in pedestrian traffic in recent decades, the Grey Street Complex remains a hub for popular economic activity in the city. Meanwhile, the physical presence of Indian South African business operators in the Grey Street Complex has dwindled considerably, giving way to a pronounced concentration of migrant business operators from African and Asian countries. As in Johannesburg, these vendors have been exposed to several bouts of orchestrated violence over the past two decades, most notably in 2008 and 2015 (Crush and Ramachandran 2015; Tella 2016). We began our fieldwork in September 2019 at the time of a major outbreak of coordinated xenophobic attacks in Johannesburg, and only six months after Durban had itself experienced a similar episode that led to the deaths of three people (Landau 2019). These events have had an acute impact on the lives of our migrant interlocutors, some of whom have now left South Africa permanently. By lending an affective intensity to our fieldwork, these circumstances yielded rich ethnographic insights into the lifeworlds of Durban's migrant population. ${ }^{2}$ It is here that we locate this article's primary empirical contribution.

\footnotetext{
${ }^{2} \mathrm{~A}$ note about our methodology may be helpful here. Most of our semi-structured interviews were conducted with business operators (shop owners, street vendors) working around the Grey Street Complex. Although some of our interlocutors were women, our interviewees reflect the markedly high ratio of men to women among operators in the district - a pattern observable in other inner-city districts in South Africa where popular economic activity is concentrated (Charway 2019). The majority of those whom we interviewed were African migrants and Indian South Africans, both of whom are well represented among business operators, although we also spoke with Pakistani migrants and black South Africans. We spoke to people from nineteen African countries (Botswana, Burundi, Côte d'Ivoire, Democratic Republic of Congo, Ethiopia, Ghana, Kenya, Madagascar, Malawi, Mozambique, Nigeria, Rwanda, Senegal, Somalia, South Sudan, Sudan, Tanzania, Uganda and Zimbabwe). Our capacity to generate empathetic connections with African migrants was facilitated by our respective positionalities: Francis is a black South African citizen who was born in Zimbabwe but who is capable of 'passing' as a 'local' resident, particularly because he has an advanced proficiency in isiZulu
} 
In the aftermath of these xenophobic attacks, we found it striking that our migrant interlocutors expressed far more consternation about their everyday experiences of intimidation in their face-to-face encounters (often perpetrated by middle- and working-class residents) than about the threat of riots and looting (associated with young unemployed men) that have dominated media coverage (Neocosmos 2010: 118). The first half of this article further elaborates this observation in conversation with Katsaura. Using the example of greeting practices, we demonstrate how migrants understand the 'routines, rituals, and rhythms' that Durban's residents share to have been 'weaponized' against them as instruments of intimidation and humiliation. We structure our analysis around the experiences of three men with whom we shared particularly evocative research encounters: Ally (from Tanzania), Mr Abdo (from Sudan) and Rashidi (from Tanzania). ${ }^{3}$ We also draw on reflexive and observational fieldnotes that are informed by our embodied knowledge of Durban as a habitat, foregrounding our respective positionalities as a multi-ethnic and international research team (Sharma et al. 2009).

Katsaura himself is keenly aware of the xenophobic 'micro-aggressions' that pervade migrants' everyday interactions in Johannesburg. For our migrant interlocutors in Durban, however, these dynamics of 'ethno-national misrecognition' feature so prominently in their encounters with 'locals' that their very capacity to inhabit the same urban everyday is increasingly thrown into question. In conversation with Erving Goffman, we argue that this is because the mundane forms of reciprocity from which migrants in Durban are routinely excluded are critical to the practices of place making through which they secure livelihoods and build a sense of belonging (Larkin 2016: 634).

The second part of this article strikes a more hopeful chord. We demonstrate how Muslim migrants develop and participate in forms of mutual recognition, both with fellow migrants and with Indian South Africans, which enable them to tacitly resist these exclusionary dynamics. Our discussion complements the case presented by Katsaura (2018: 12) of a Pentecostal church in Johannesburg that, he shows, provides routine opportunities for ethnically diverse residents to feel and act similarly in one another's presence. Using the case of Muslim networks and mosques in Durban's CBD, we extend Katsaura's account by tracking how these religious mutualities spill out into the streets and envelop the wider city. In doing so, we build on recent work in the anthropology of Islam which spotlights how Muslims' experiences of Islam are constructed and complicated within and as part of their everyday lifeworlds (Deeb 2015). We demonstrate that Muslim socialities extend a sense of welcome to migrants, providing them with opportunities to participate in mundane interactions such as greetings from which they are otherwise excluded, and thereby reinforce their capacity to invest their energies in the city. As we go on to argue, these Muslim forms of mutuality constitute an enabling condition for the everyday life of the CBD itself, holding open opportunities for interethnic and international reciprocity that would otherwise be impossible.

and isiXhosa (see Dube 2017); Fred is a black Ghanaian man who has lived in South Africa for eight years; Ben is a white British man who has never lived in South Africa. The ethnicized identities we were assigned correspondingly hindered our efforts to engage with black South Africans about these issues. Further research is needed to address this gap.

${ }^{3}$ All names have been changed. 


\section{Unwelcoming gestures}

5 p.m. downtown. We [Ben and Fred] are looking for a bar. After passing some spots which don't look very welcoming, we settle on one at a major street intersection. We joke with the bartender and ask for a nip of whisky and some ox-head soup. We sit down at an empty section of couches. The bartender places the soup on the table in front of us and we joke a little more together. We've hardly tasted the soup when a man walks past us and, as he does so, theatrically cranes his neck around as if to get a better look at us. A few minutes later, a group of four middle-aged men in white dress shirts sit down on the couches around us and continue their conversation without acknowledging our presence; we do likewise. The first man returns to our table, this time leaning over us to greet the men sitting beside us, saying loudly, 'Umlungu ... ikhona imali ... [A white person ... there is money ...].' He then turns to us and, smiling exaggeratedly, greets us in isiZulu: 'Sawubona' (literally, 'I see you'). With Ben struggling to form a response as he shakes his hand, Fred tentatively responds for us both: 'Ngiyaphila.' The man continues to speak at us in isiZulu, knowing that he has taken us well beyond the limits of our isiZulu comprehension. Neither of us feel that this is a particularly welcoming gesture. The man finally walks away. Fred subtly remarks to Ben that we should finish our drinks and go. Before Ben can reply, the men pull our table, together with our soup and drinks, towards them. The table's metal legs drag noisily against the floor. ${ }^{4}$

This encounter serves as an entry point for a discussion about the everyday dynamics of exclusion faced by migrants in Durban. The episode cannot be understood without reference to the fact that Ben is a white British man and that Fred is a black Ghanaian man. We understand these racial and ethnic designations to be a performative effect, one that is achieved through the interplay of bodies (as sensory and situated objects) and embodied practices of perception and judgement (Amin 2012; M'Charek 2013). In the case of Ben, the men's reading of his bodily markers (e.g. phenotypic features, dress practice, etc.) combined with his positioning in space (white South Africans rarely frequent downtown bars) presumably led them to infer that he is not South African. In the case of Fred, the men likely judged from his phenotypic features and accent that he comes from a West African country (as many Durban residents do). While the man who greeted us exposed both Ben's and Fred's limited isiZulu comprehension, he in fact directed more attention to Fred over the course of our interaction. This was consistent with our broader experience in Durban, whereby Francis and Fred were held to a much higher standard than Ben with respect to exchanging isiZulu greetings. Indeed, we encountered several people in town who, despite exhibiting a high level of competency in English language, entirely refused to speak to Fred in either English or isiZulu on account of the fact that his isiZulu was not highly advanced.

This ethnographic moment was particularly resonant because it occurred just one hour after Mr Abdo, a middle-aged Sudanese man who works as a street vendor in town, described a strikingly similar kind of experience. Mr Abdo uses isiZulu greetings to capture the attention of people who pass his stall, a capacity that many migrant groups in South Africa develop as a means of navigating social

\footnotetext{
${ }^{4}$ Fieldnotes, 16 September 2019.
} 
encounters (Katsaura 2018: 9). Mr Abdo observed that black South Africans routinely use these business transactions as an opportunity to humiliate him for his limited language comprehension; they often continue to speak at him in isiZulu even when they have gathered that he does not know the language. He understands this to be an attempt to make him feel vulnerable:

I call it intimidating behaviour because that's what it is. Any aggressive or arrogant language is intimidation; that's how I define it. They try to bring you down using the Zulu language. They ask, 'Why don't you learn our language?' That thing is there every time, whether they are mature or young.

This perception was widely shared by our migrant interlocutors (see also Dube 2017: 402). Another man elaborated further on the matter:

Locals all have their own way of letting you know that you're not welcome. After they greet you in their language, what else can you do when it gets to the point where you can't go any further [with the conversation in isiZulu]? They are imposing their language on you; they are claiming their space by making you feel uncomfortable and intimidated.

Beyond humiliation and intimidation, some migrants also indicated that these encounters are used as a vehicle for extorting money out of them (see also Katsaura 2018: 9). One of our Tanzanian interlocutors, Ally, gave a good example of these dynamics:

We [migrants] experience intimidation every day, even when using public transport. When they ['locals'] see you are Muslim, they start using bad words towards you. It isn't directly Islamophobia, but they will speak about foreigners as makwerekwere [derogatory term for migrants] saying they must go to their country. Sometimes even the [minibus taxi] driver will not return your change, and even if you ask them for it they just ignore you.

This incident is particularly striking given that it is likely to have taken place in plain view of other passengers (see also Dube 2017: 404; Hankela 2020: 938; Siziba 2016: 132-4).

\section{Politicizing isiZulu}

As these examples suggest, many migrants routinely experience 'micro-aggressions' in their ordinary social encounters with black South Africans in Durban. Set within the broader frame of South African history, several factors have facilitated the emergence of these exclusionary practices and the figure of the 'foreign national' at whom they are directed. Chief among these is an ethnic politics of citizenship, mobility and residency rights that has grown out of the apartheid-era displacement of black South Africans (Landau 2011: 5). In the post-apartheid era, this has been compounded by the enduring reliance on migrants for 'cheap, disposable labour' at a time of sharpening inequalities and 'jobless urbanization' (Fourchard and Segatti 2015: 3, 5). Government officials and institutions have also exacerbated and legitimized xenophobic sensibilities through their stigmatization (and attendant mass deportation) of migrants for allegedly infringing upon South Africans' hard-won rights to employment and housing (ibid:: 3, 5, 8). 
These determining factors are notably pronounced in the context of Durban where the salience of xenophobic sensibilities needs to be understood with reference to more localized struggles and constructions of political subjectivity (Monson 2015: 148). The province of KwaZulu-Natal, incorporating the former Zulu 'homeland' established under apartheid, constitutes a gravitational centre for Zulu ethnic politics in South Africa, often being presented as the territorial successor to an earlier 'Zulu kingdom' (Harries 1993: 119). In the final decades of the twentieth century, the region saw an intensification of Zulu ethnic consciousness catalysed by the ascent of Mangosuthu Buthelezi's Inkatha Freedom Party (IFP) and its use of Zulu cultural idioms to mobilize supporters around a putative 'Zulu nationalism' (ibid.). The enduring appeal of this politics is indicative of the renewed plausibility that ethnic constructions of citizenship have acquired in South Africa in recent decades amidst growing disillusionment about the state's capacity to deliver on its promises of well-being for all. While the lived identities of Zulu residents are more hybridized than is often presumed (Piper 2003), there can be little doubt that these ongoing struggles to define belonging and secure citizenship have further politicized boundaries between 'local' residents and African migrants in KwaZulu-Natal and beyond.

Setting contemporary xenophobic practices against this backdrop of ethnic politics also helps to explain why isiZulu has become a privileged site and means of contestation over boundaries of belonging. IsiZulu enjoys widespread currency as a lingua franca among black residents in other parts of South Africa, not only because of the pronounced concentration and distribution of isiZulu speakers across the country, but also on account of its 'prestige' status relative to other African languages (Harries 1993: 109-10; Rudwick 2006: 85-9; Sanders 2016: 8-9). Despite this ubiquity, a 'native-level' proficiency in isiZulu is widely taken to be indexical of a speaker's 'Zuluness', having been integral to the construction of Zulu identity over the course of the twentieth century (Harries 1993: 112-13). In KwaZulu-Natal specifically, isiZulu speakers have been shown to exhibit a greater reluctance to 'linguistically accommodate' non-isiZulu speakers, especially in the case of African migrants, further strengthening a popular impression that their claims to collective identity and belonging are 'exclusionist' (Rudwick 2006: 66, 68, 86). We had first-hand experience of these dynamics on first meeting Ally at the Early Morning Market, an area dominated by isiZulu-speaking business operators. When Ben and Ally greeted one another in Kiswahili, the facial expressions of those around us oscillated between bewilderment (at a white person speaking an African language) and indignation. Registering these bodily responses, Ally instinctively broke out of Kiswahili and switched to English to appease our onlookers.

These sociolinguistic practices were instrumentalized in pursuit of explicitly political ends in the 1980s and early 1990s during the bloody conflict between supporters of IFP and rival parties. IFP supporters often spoke isiZulu with a deeper intonation to signal their links to rural areas (where IFP had its base), with attacks being targeted at non-native isiZulu speakers and those with accents characteristic of urban townships (Dlamini 2005: 91-2). The parallels here with the contemporary use of isiZulu to identify and 'intimidate' migrants are unmistakable, underlining the importance of reading these practices as part of a longer history of ethnolinguistic politics in KwaZulu-Natal, one in which the use of isiZulu to enact social difference has often invoked an exclusive claim to belonging and the rights of citizenship. 
These regional contestations have had reverberations at a national scale: leveraging the government's desire to 'placate' them, Mangosuthu Buthelezi (in his time as Minister of Home Affairs) advanced draconian immigration reforms, and Goodwill Zwelithini (the Zulu king) has joined Buthelezi in using antimigrant rhetoric with relative impunity (Buthelezi and Skosana 2018: 122; Tella 2016). In what follows, we are principally interested in how these xenophobic sensibilities materialize at a local scale in the vernacular practices of ethnic and national exclusion that we spotlight in Durban.

\section{Weaponizing the everyday}

The experiences of our interlocutors detailed above are indicative of a distinctive gestural politics in Durban whereby salutations have undergone something of a "weaponization'. 5 Far from offering 'an antidote to the "elbow test" imposed on foreigners', as Loren Kruger (2013: 232-3) hopes, it would appear that this 'sawubona culture' has been 'hijacked' and made to serve the same exclusionary ends. ${ }^{6}$ We elaborate this point with Erving Goffman (1963; 1971), whose work has proven fruitful for researchers investigating similar dynamics in Johannesburg (Katsaura 2018; Siziba 2016). Goffman (1971: 75, 78) conceptualizes greetings as 'rituals' through which participants not only become more 'accessible' for heightened interaction, but also extend 'social recognition' to one another. Given that such moments of recognition exchange are constitutive of the 'ethno-national mutualism' that Katsaura (2018) identifies within the urban everyday, we find greeting practices to be particularly fruitful to 'think with' here.

In the context of Durban, 'foreignness' is enacted both on and with the bodily markers of migrants, materializing most conspicuously in their speech; it is no coincidence that the ubiquitous ethnic slur, makwerekwere, is an onomatopoeic caricature of migrant language practices. As a 'stigmatizing attribute', foreignness 'disqualifies' migrants from full participation in ordinary social interaction (Goffman 1963: 3-5). To reduce the social 'obtrusion' of this attribute in goaloriented encounters such as business transactions, we saw above that many migrants in South Africa acquire a capacity to exchange greetings in isiZulu (ibid.: 31, 138). This is a good example of how, as Karie Morgan (2015) demonstrates in Johannesburg, residents can use greetings to experiment with different selves that may elicit new possibilities of belonging.

\footnotetext{
${ }^{5}$ Here we adopt a broad definition of gesture that is not limited to 'paralinguistic' behaviour (e.g. hand gestures that accompany or 'stand in' for speech), but includes a variety of routine 'bodily practices that express social and cultural meanings' that are not always easy to articulate verbally (Elyachar 2011: 84; Handler 2009: 283). The term 'isiZulu' is particularly useful in this respect since it can also be used to denote characteristically 'Zulu' cultural norms.

${ }^{6}$ The 'elbow test' refers to a series of incidents that took place amidst the mass xenophobic violence in 2008 and 2019 in which Johannesburg residents were attacked when they failed to 'properly' pronounce the isiZulu word for 'elbow' on command (Sanders 2016: 115-16; Ramaphosa 2019). As Mark Sanders (2016: 116) observes, such 'tests' serve as an 'improvised form of popular border control' that resembles a 'hyperbolic parody' of law enforcement practices from the era of apartheid to the present day. It is notable that the aforementioned incidents took place in a city which (unlike Durban) has never been a majority native isiZulu-speaking settlement, and indeed that at least one victim was a South African-born citizen (ibid.: 8).
} 
Critically for our analysis, these 'arts of impression management' rely on a degree of cooperation between 'normals' and stigmatized individuals - a form of reciprocity that is markedly absent in the accounts that we discussed above (Goffman 1963: 30, 130). Where migrants are explicitly admonished for not having a strong grasp of isiZulu, this amounts to a refusal to cooperate in this ritual of mutual recognition, ostensibly because of the individual's perceived failure to 'assimilate' or deferentially perform a 'local' identity. When black South Africans do cooperate in these ceremonies, they can be so assiduous in upholding a migrant's 'assimilated' self-image that they expose their limited capacity to embody these behavioural norms.

In both instances, by reinscribing social boundaries, 'local' residents further 'discredit' migrants and their claim to be full and legitimate cohabitants of the CBD, thereby reinforcing their socio-spatial marginality (Goffman 1963: 130). Somewhat perversely, migrants are obliged to participate in these everyday rituals since the social stakes of deviating from these norms (let alone retaliating) are so much greater for migrants than for black South Africans. Conscious that their claim to be legitimate cohabitants of the CBD is conditional on - and routinely discredited through - these highly contingent encounters, our migrant interlocutors reported experiencing a state of heightened background anxiety.

Importantly, the 'weaponization' of salutations does not impute conscious 'intent', even if this question features prominently in the psychic lives of migrants and their 'meta-pragmatic' reflections (Sheridan 2018: 241). With Ash Amin (2012: 96), we understand ethnicization to be structured by embodied routines that guide how people perceive and respond to bodily markers and that 'trigger' distinctive sequences of action and feeling. While these exclusionary practices can certainly be undertaken consciously, often they are likely to be enacted with only peripheral awareness (Handler 2009: 284). The question of 'intent' is also complicated by the fact that 'locals' may be disincentivized from contravening politicized norms of linguistic non-accommodation by the threat of 'in-group' sanction (Bailey 2000: 102; Goffman 1963: 18). Mindful of these complexities, we take weaponization to denote the process by which exclusionary logics are scripted into the mundane rituals of social interaction such that they foreclose opportunities for migrants to cultivate selves that elicit a sense of belonging to the city, thereby reproducing their socio-spatial marginality.

In what follows, we build on our understanding of gestural politics to consider its results: a wider set of dynamics that restrict migrants' access to livelihood opportunities and personal security. We then discuss some examples of the ways in which migrants cultivate livelihood networks as a means of rendering the quotidian city habitable amidst conditions of exclusion and precarity. These networks provide a useful entry point for examining how Muslim forms of sociality might enable migrants to 'disarm' Durban's weaponized everyday.

\section{'Islam is our basics'}

In her research in Durban's CBD, Shauna Mottiar (2019: 288) demonstrates how street traders develop ephemeral livelihood networks that assist them in forming business collaborations and anticipating police crackdowns on unlicensed 
vendors. To these ends, greetings provide an important means by which business operators can elicit encounters and consolidate social ties with fellow traders (Goffman 1971: 73, 79; Kirby 2020: 567-9). Because of migrant traders' limited capacity to participate in protracted isiZulu greetings, it is difficult for them to incorporate black South Africans into their livelihood networks. This reinforces a broader sense of 'disconnect' which makes migrants less willing to establish business collaborations with 'locals'. In Mr Abdo's words:

It is very hard to make links with local people. If you're going to develop a business attitude [i.e. an enterprising persona], others want to take advantage of you, so it's very difficult to get into partnerships. With locals, their law outweighs yours, so you are the victim.

The 'law' that Mr Abdo understands as privileging the rights of 'locals' over those of migrants encompasses not only the formal justice system but also the jurisdiction that 'locals' exercise through more informal mechanisms of social regulation in the CBD. For this reason, Mr Abdo prefers to develop business networks with fellow migrant business operators instead of black South African residents:

In order to get the truth on the ground, to acquire business information, I pick people like Somalis or Ghanaians because I can trust them. You can't get it from locals. With these [groups] you can sit and share. You are confident as you're all the same; the law protects you all the same.

Mr Abdo's social precarity is particularly heightened because he is one of a very small number of Sudanese in Durban, meaning that he has no access to networks grounded in a shared language or national identity, only fellow migrants facing a similar set of everyday challenges (Mottiar 2019: 288). Mr Abdo also observed that his Muslim identity has not helped him to develop business partnerships. $\mathrm{He}$ even found that people sometimes "use that word "Muslim" ... for different reasons [i.e. in bad faith]', requiring him to 'be very observant to differentiate' who to 'keep close' to preserve his 'safety'. Nevertheless, he acknowledged that, had he not been a Muslim, he could not have secured his prime vending space next to Grey Street Mosque (Juma Masjid), where the mosque trustees 'rent out stalls for lower prices'.

The case of Rashidi, another street vendor in town, offers a different perspective on the importance of Muslim socialities for migrants. Rashidi came to Durban in 2010 from Tanzania; his stall is located beside the shop of his Burundian friend who has himself lived in Durban since 2000. In stark contrast to Mr Abdo, Rashidi participates in a tight-knit livelihood network populated by young men hailing from across the African continent, particularly East and Central Africa. The connection these men share is not ethnic or national so much as transregional, structured by their shared use of Kiswahili and - critically for this discussion their Muslim identity. Rashidi provided a highly textured account of how Islam generates solidarity and mutual responsibility among his friends:

Islam is like our basics. This man [points] comes from Ivory Coast; you can see how far he is from Tanzania, but we all meet [together at this location]. We are all brothers. Islam is what is guiding you in life. If you believe, you will be protected. If one Muslim man dies here [in Durban] because of hunger or whatever, we all will get punishment. 
Another Muslim street vendor from Tanzania made a similar allusion to collective resilience in the face of adversity and injustice, describing Muslim sociality in Durban as being "like "thug life", (see Stanford 2011). When we asked him to clarify what he meant by this, he invoked the Tanzanian idiom 'unity is strength' (Kiswahili: umoja ni nguvu). Accordingly, the 'belief' (Kiswahili: imani) that Rashidi speaks of entails not only a commitment to a set of metaphysical propositions, but also what AbdouMaliq Simone (2014) describes as the 'miraculous' affordances that religion can extend to urban residents. Islam provides a platform for solidarity and collaboration in view of 'the fundamentals of the city' or what Rashidi calls 'our basics' (Kiswahili: misingi yetu).

These Muslim socialities materialize in an alternative gestural commons - an urban everyday to which Rashidi and his friends have unrestricted access. Rashidi directed our attention to Islamic salutations:

If someone calls your name or greets you in the street, you will ask, 'How do you know me?', so it's easier to say as salaam wa alakum.

By 'easier' here, Rashidi spotlights how Islamic salutations facilitate everyday encounters, providing an established 'script' for 'good faith' interaction, even between unacquainted Muslim residents. This dynamic relies on a prescribed behavioural repertoire, which, in accordance with prevailing Islamic norms, obliges the recipient to swiftly reciprocate with a corresponding 'formula', thereby establishing a sense of mutual recognition (Caton 1986). This is well illustrated by a Malawian Muslim's account of his first arrival in Durban recounted by Shahid Vawda (2017: 57):

After I got off the taxi at Umgeni Road, I saw a mosque [the Grey Street Mosque]. It was Esha time [the evening prayer]. I saw some people coming out of the Mosque. I simply went to them and greet them 'As salaam wa alakum'. They had to respond. I asked them to tell me where [the mosque] was. Someone took me there.

Islamic greetings, then, provide a legitimate platform for generating and projecting a sense of mutual recognition and respect that, given Durban's gestural politics, would otherwise be impossible using isiZulu or other languages. This is particularly important for Rashidi and his friends, who, as retailers, are regularly exposed to dynamics of 'misrecognition' in their business transactions when 'locals' discredit the 'assimilated' selves that they perform (Katsaura 2018: 6). Given that, as Rashidi explained, migrant business operators are unable to retaliate when they feel intimidated or humiliated by 'locals', let alone openly resist such behaviour, these forms of mutuality and alignment transform the urban everyday into a site of not only exclusion but also tacit resistance (Mottiar 2019: 288).

\section{A sense of welcome}

Islamic greetings form part of a wider sensory landscape of Muslim 'welcome' in which Rashidi and his friends participate. Unlike Mr Abdo, who occupies a central vending space, Rashidi's Kiswahili-speaking network is located on the periphery of the Grey Street Complex in an area where a number of ethnolinguistic 
'clusters' of African migrants have been able to consolidate their presence and cultivate a sense of belonging in a way they could not in a more central location (Masquelier 2019: 68). These patterns of emplacement are a direct outcome of their efforts to navigate Durban's gestural politics, and specifically the disapproval and even hostility directed by black South Africans at visible displays of migrant sociality and the use of non-isiZulu languages. It is also no accident that their street remains within earshot of the azaan (call to prayer) from West Street Mosque. Rashidi explained the significance of this for his network:

When we hear the azaan we go to the mosque; it's something that reminds you to go to pray. The Arabic language is like a code; it makes us feel welcome wherever we go.

For Rashidi, then, the sound of the azaan and the materiality of Arabic as a sensory object are not only affectively resonant but also enact a certain 'aesthetic commonality', one that transmits a sense of collective belonging grounded in a shared 'Muslim-ness' (Alhourani 2015: 113).

Expanding on this, Rashidi went on to describe the sense of security and orientation that the mosque extends to Muslim migrants:

The mosque is like a defence mechanism for our lives; it is like a guidance. When we [Muslims] arrive in a new place, the first thing that we do is to ask where the mosque is; we know we will be welcome there at the mosque and not feel lost. When you go to church, you don't get a welcome; we do at the mosque. When we go there, they welcome us, and if you have a problem, it's easy for them to understand you. You can find Indians and Muslims here; Indians are like our brothers. They give us a small amount of money to survive, to support, to help us have a start.

Here it becomes clear that Rashidi understands Muslim forms of sociality not only to reinforce bonds of mutual obligation within his primary livelihood network of fellow migrants ('Islam is like our basics'), but also to provide a platform for solidarity and mutual intelligibility with Indian South Africans. As in the case of $\mathrm{Mr}$ Abdo and his vending space at Grey Street Mosque, these mosque-based socialities help Rashidi and his friends to 'have a start' in the city by providing access to financial support. Furthermore, despite having lived in Durban for nine years (and indeed his Burundian friend having lived in the city for two decades), Rashidi and his friends continue to find security and belonging in the 'welcome' that they receive from the established Indian South African Muslim population of the city at the West Street and Grey Street mosques.

While several of our interlocutors, Rashidi included, have first-hand experience of xenophobic violence and looting, we found no evidence that the performance of a discernibly Muslim identity can guarantee migrants protection. Nevertheless, several people spoke at length about the forms of moral and practical support that they have received from Indian South Africans at the mosque as a means of negotiating these escalating politics (see also Sadouni 2014). As Rashidi explained, shedding further light on the protective logic of ethno-regional clustering in town:

We Muslims, when we go to the mosque, it gives us a way to stay alongside them [i.e. black South Africans]. They [at the mosque] tell us, 'Don't stay in that area, don't do business in location [i.e. black-majority townships] because there's no one to guard you 
or support you; do business in town because it's more safe.' That language gives you hope. So there are only a small number of Muslims in location. In location they attack shops; in town, they can't because there's so many [shops].

When Rashidi describes how the mosque presents Muslim migrants with 'a way to stay alongside' the black South African population here - quite literally operating as an 'enabling condition' or infrastructure (Hentschel 2014) - he is not only referring to a sense of gratitude for the practical advice that they receive from fellow worshippers. As the spatial distribution of migrant business operations across the city suggests, it is common knowledge that setting up isolated spaza (convenience) stores in location is highly perilous for migrants - as one Ethiopian woman told us, 'only Somalis' are bold enough to risk doing so. Rather, Rashidi is also alluding to the legitimacy that the mosque as a frame for social interaction confers on their presence in town. More specifically, the mosque presents 'a way to stay alongside' black South Africans because it is a space in which Muslim migrants do not need to negotiate, justify or defend their presence as they do elsewhere in the CBD. As in the case of Katsaura's (2018: 12) Pentecostal church in Johannesburg, the performance of obligatory prayer provides routine opportunities for ethnically diverse residents to enter one another's presence 'at the intersection of intimacy and strangeness': a space where the mundane rituals of social encounter (such as the exchange of greetings) are upheld and, accordingly, moments of mutuality are generated. The 'hope' that accompanies the suggestion that Muslim migrants 'do business in town' derives once again from $a$ sense of welcome - an invitation to cohabit and fully participate in an urban everyday associated with the established Indian South African community.

Accordingly, the mutualities that are generated within the mosques have a tangible impact on the ambient life of the district, being mediated through the exchanges between Indian South Africans and Muslim migrants in the streets, and indeed through the very sound of the azaan as an anchor for their life projects. In other words, West Street Mosque is an enabling condition for the daily presence of Rashidi and his friends in the CBD. As such, their very emplacement constitutes a form of what David Garbin (2012: 402) calls 'believing in the city': an act of placing faith in 'the possibility of sustaining, projecting or even reinventing a sense of self through urban religious place-making'.

\section{Ambivalent sites of mutuality}

We are wary of providing a romanticized treatment of these forms of Muslim sociality in Durban, particularly given the Orientalist logics that continue to inform depictions of Muslim groups as homogeneous entities. South Africa's Muslim population has long been markedly diverse, in terms of both theological orientation and ethnocultural identity. The history of the Grey Street and West Street mosques themselves attests to this - the former associated with Memon-speaking Indian South Africans belonging to the Barelvi movement, and the latter with Surtee speakers in the more reform-oriented Deobandi tradition (Jeppie 2007: 20). This plurality has been augmented in recent decades by migration flows from countries with large Muslim populations (Alhourani 2018: 191). African migrants arriving in Durban, where most Indian Sunnis belong to 
the Hanafi school of Islamic jurisprudence, typically adhere to the Maliki and Shafi'i schools. Amidst this plurality, diverse Muslim residents experience a sense of belonging to a single 'Muslim public', sharing certain aesthetic sensibilities and gestural routines that mediate and project a form of Muslim mutuality (Alhourani 2015: 115). Importantly, however, this sense of mutuality is still punctuated by dynamics of ethnic and racial distinction embedded in South Africa's social landscape (Sadouni 2019: 119, 156).

For a rather less effusive perspective on the relationship between Indian and black Muslims in Durban, consider the following account provided by Ally:

In the masjid [mosque] there is discrimination from fellow Muslims, especially Indian Muslims. The research shows that the most discrimination comes from Indians towards others, especially if you are African. I was discriminated against in madrasa [an Islamic education institution] where I was studying deen [guidance for following the Islamic way of life]. In madrasa you will find even the principal saying openly that 'These African students just come to eat here,' and every blame goes to them. I decided to face the principal who himself was head of discrimination towards African students, and I told him straight away that Islam is for everyone and Allah Ta'ala doesn't look at the colour [of your skin] or social status; Allah Ta'ala looks at your actions and your heart. In masaajid [mosques] similar situations happen: even when you enter masjid they suspect that you are a thief.

Over the course of our conversation, Ally went on to describe the contested nature of greetings between Indian and black Muslims, indicating a very different outlook to that of Rashidi:

You know, the first time I ever felt discrimination was when I came to South Africa. Even when you give salaam [Islamic greetings] to them [Indian Muslims], if you are African they will respond negatively. Even when they greet you as a black man, they just say 'assalamu alaykum, sheikh', which is a way of referring to you as inferior. 'Sheikh' means to them that you are inferior; that you are a person who cleans toilets and is doing a rubbish job. You see, they don't use this term to refer to each other; they only apply [it] to black men. We have even just accepted this [behaviour] so life can go on; they will never change their behaviour towards Africans especially.

In Ally's experience, then, Islamic salutations are themselves susceptible to a parallel gestural politics to that which is associated with isizulu greetings discussed above. Where in the context of Tanzania the term sheikh is widely used as an honorific title (Kirby 2020: 567), Ally understands that Indian South Africans use it to confer on black Muslims an exaggerated status which is incongruent with their prevailing attitudes towards them.

These frictions may derive from the general 'pathology' of 'mixed' interaction, with 'normals' often over-correcting their behaviour to accommodate stigmatized individuals (Goffman 1963: 18-19, 30-1). However, they should also be understood with reference to wider dynamics of racial and ethnic exclusion as they materialize within the Muslim community. As Samadia Sadouni (2019: 73) demonstrates, claims to a Muslim identity by migrants (both African and otherwise) are typically received unevenly by Indian Muslims depending on their proficiency in Arabic and whether their country of origin is majority Muslim. These perceptions are compounded by the fact that, in KwaZulu-Natal, Islam has 
often been understood by Indian and black South Africans alike to 'belong' in some sense to the Indian population, having long served as a site for contesting and consolidating a sense of 'Indianness' (Kaarsholm 2011: 109, 112).

African migrants often find these attitudes perplexing. Ally explained that 'Islam looks very strange to local African people', adding that when he has participated in $d a$ ' $w a$ (proselytization) activities, 'They tell you, "No, I cannot follow the Indians' religion, because the Indians never gave Islam to us locals." Similarly, Rashidi recalled how, on first arriving in Durban in 2010, he found that 'people here [i.e. "locals"] at first found it hard [to process] that black people are Muslim, asking "Why are you taking on Indian culture?" Rashidi described how he has often needed to explain: 'Here in Africa we were Muslim before Indians were; there is no Indian prophet, whereas Abraham's sons grew up in Egypt and some became citizens of Egypt.' 'We black people are a special people,' he continued. 'God sent us [Muslims] to Africa for a reason.' Here Rashidi rhetorically resituates the African Muslim population away from the spatial and temporal margins of the Muslim world towards its centre, aligning his own migration experience within the unfolding narrative of Islamic history (Kirby 2017: 68). In doing so, he not only disrupts the sense of 'ownership' over Islam that many in Durban attribute to the Indian population, but also grounds his own claim to belonging to the city (as a constitutive part of the African continent). Indeed, this reflects a wider trend in South Africa in recent decades as African migrants, together with black South Africans, have increasingly asserted claims to an authentic Muslim identity, often cultivating new sites of Islamic expression and authority (Alhourani 2015; Kaarsholm 2011; Sadouni 2019). Ally's experience of being marginalized by Indian Muslims speaks to these frictions within the Muslim community, together with broader dynamics of racial and ethnic exclusion.

\section{Towards the urban whole}

While a shared identity with South African Muslims thus grants Muslim migrants access to livelihood assistance (financial support and vending spaces, for example), and although some like Rashidi are grateful for a sense of 'welcome' that allows them some claim to belonging in the city centre, these reciprocities are often ambivalent and incomplete. Rather than conceptualizing this Muslim mutuality in Durban as a 'thick' form of solidarity, we instead suggest that it operates more like an 'enabling condition', an 'infrastructural experiment' for generating the possibility of reciprocity between Indian South Africans and African migrants who may otherwise have little in common (Hentschel 2014: 162).

We want to conclude by insisting that these practices of religious solidarity cannot be disentangled from the configuration of urban space itself. As noted above, the physical presence of Indian South Africans in the Grey Street Complex has diminished somewhat in recent decades. This trend has its roots in the 1950s following the implementation of the Group Areas Act and the racial zoning plans that accompanied it, a development that led to decades of protracted struggle and uncertainty about whether Indian South Africans could continue to reside and do business in the Grey Street Complex (Rosenberg 2012: 126; Sharma 
2016: 94-124). From the late 1980s onwards, Indian business operators increasingly relocated to suburban shopping malls in Indian-dominated townships such as Chatsworth and Phoenix, and later to suburbs including Overport and peripheral towns such as Umhlanga; this shift was accelerated by a rise in crime in the CBD and the growing presence of migrant business operators (Sharma 2016: 120). Another factor, as one Indian trader explained to us, is that the children of Indian shop owners now have better access to education opportunities, with many becoming 'doctors and lawyers' instead of inheriting the family business, leaving 'foreigners' to take their place. Nevertheless, the emblematic significance of the Grey Street Complex for Indian South Africans - a landscape resonant with emotional attachment, collective memory and 'diasporic nostalgia' - has intensified enormously. A proliferation of popular histories, literary works and Facebook groups about the Complex attests to this development (Kumar 2019; Moreillon 2019; Pahlen and Stiebel 2017; Sharma 2016). To invoke Sharad Chari (2014: 158), it is through the 'remains' of Grey Street's 'settled landscape, its banal built forms and habitual routines, its ... prayer calls' that Durban Indians maintain a sense of 'ethno-racial mutuality', one that was first forged in the early twentieth century amidst the exclusionary dynamics of white supremacy. This is epitomized by the iconic Grey Street Mosque Precinct, with its spectacular gold minarets and warren-like shopping arcades.

Despite these associations with a putative 'Durban Indian mutuality', we propose that Grey Street's urban everyday provides glimpses of a 'mutuality yet to come' that Chari anticipates, one that transcends these ethnic and national boundaries. As Sadouni (2019: 131) demonstrates in the suburb of Mayfair in Johannesburg, part of the 'legacy of apartheid' is a concern on the part of Indian South Africans for protecting 'their investments in a place where they resisted forced removals and struggled to gain recognition of their rights as citizens', just as Durban's Indian community fought for their right to inhabit the Grey Street Complex. The protective 'welcome' that Indian Muslims extend to Somali migrants in Mayfair rests on an expectation that they will 'reinforce the economic activities and preserve the religious environment that the Indians had built over the last century' (Sadouni 2014: 398).

Similarly, in Durban, given the dwindling number of Indian South Africans working and praying in the CBD, Muslim migrants from across Africa and Asia are in many respects the new 'custodians' of the ritual and sensory composition of the Grey Street Complex. After all, it is African and Asian migrants who now constitute the majority of worshippers at the Grey Street Mosque (Desai and Vahed 2011: 45). While these groups are poorly represented among mosque trustees and in leadership positions, they do not merely shelter under the canopy of Durban's 'Casbah' and the layers of social memory that tie generations of Indian South Africans to the district. Rather, they are actively contributing to its reproduction as a sensory habitat through their participation in mundane rituals and rhythms. Just as Rashidi relies on the Indian Muslim community for the 'hope' that he needs to sustain his belief in the possibility of pursuing his life project in Durban, the Muslim migrant population in turn helps to sustain the distinctive composition of the Grey Street Complex, which remains so evocative for the city's Indian community. In other words, Muslim associations in Durban generate a form of interethnic and international mutuality structured around different but fundamentally entangled modes of belonging. 
Critically, these dynamics have wider implications beyond the life projects of Muslim residents alone. By joining Kelly Gillespie (2014) in thinking with 'the urban whole' - to 'insist on [the] mutuality' of its residents rather than their dissociation - we propose that these Muslim forms of sociality constitute an enabling condition for the everyday life of the CBD itself. If Muslim socialities provide an opportunity for migrants to participate in an urban everyday from which they are otherwise excluded, as well as maintaining the ritual and sensory composition of the Grey Street Complex, they serve as enabling conditions for an urban everyday that holds open the possibility of a broader horizon of 'ethno-mutualism' - one in which non-Muslim and non-migrant residents who pass through the district are also obliged to participate.

\section{Conclusion}

We opened this article with a reference to Katsaura's account of an 'ethnomutualism' in Johannesburg that derives from the shared 'routines, rituals, and rhythms' organizing everyday life in the city. Following Katsaura, the first part of this article focused on the ordinary social encounters that African migrants working in Durban's CBD share with black South African residents. In contrast to the case that Katsaura describes, we demonstrated that greeting practices have been weaponized as part of a broader logic excluding African migrants from the mundane rituals of social interaction. We understand this to constitute a 'hijacking' of the urban everyday by xenophobic sensibilities, and that this threatens to render it uninhabitable for migrants by excluding them from the ordinary encounters through which a sense of mutuality and belonging can emerge. This presents an even greater challenge for migrant business operators whose very livelihoods depend on their capacity to develop expansive social networks. Collectively, these observations shed light on the importance of the ordinary rituals of interaction that Katsaura describes for broader practices of place making among migrants.

The second part of this article explored how Muslim forms of sociality enable African migrants to tacitly resist these exclusionary practices by making the urban everyday inhabitable. First, we demonstrated how Islam serves as a set of 'basics' on which migrants can construct their life projects and a sense of solidarity in the face of exclusion. Elaborating this point, we considered how Muslim greeting practices provide a platform for inconspicuous acts of mutual recognition between African migrants and how this grants them access to an urban everyday from which they would otherwise be excluded. Second, we showed how two historic mosques provide a space in which Muslim migrants do not need to negotiate their presence in the way that they do elsewhere in the CBD, offering a social frame that lends their claims to belonging a greater legitimacy and coherence. Third, we demonstrated how forms of mutuality that are generated between African migrants and Indian South Africans shape the ambient life of the CBD, with their routine interactions and the sound of the azaan mediating a broader sense of welcome from this established community.

We went on to address the ambivalence of these mutualities, revealing how Muslim forms of sociality do not guarantee protection from the dynamics of exclusion, division and vulnerability that permeate the lives of these African 
migrants more generally. Nevertheless, we argue that they continue to hold open the possibility of unforeseen mutualities - a shared everyday - between residents who would not otherwise share a 'common urban horizon' (Hentschel 2014). In conversation with recent African studies, we find the notion of 'mutuality' to be particularly suggestive because it elicits questions about the ways in which the Indian South African community might rely on the reciprocities that they share with African migrants for their own sense of belonging. By participating in the mundane rituals of Muslim sociality, migrants have emerged as the new 'custodians' of the ritual and sensory composition of the Grey Street Complex. As such, Muslim socialities do not merely 'compensate' for the exclusionary dynamics to which migrants are exposed, but actually serve as enabling conditions for the very fabric of the $\mathrm{CBD}$ as a shared habitat, the mutualities that it can sustain, and the collective energies that diverse residents continue to invest in it. These insights enrich and extend recent work on mutuality (Bjarnesen and Utas 2018; Chari and Gillespie 2014) and migrant sociality (Dube 2017; Hankela 2020; Siziba 2016) in African cities and beyond, illuminating the often unacknowledged ways in which everyday forms of religious association are reproducing and reconfiguring shared urban worlds (Larkin 2016; Katsaura 2018; Kirby 2020).

\section{Acknowledgements}

This research project was funded by a grant awarded by the Academy of Science of South Africa and the British Academy. We are grateful for the support that we received from Christopher Allsobrook, Raymond Perrier, Yasmin Ismail and the University of KwaZulu-Natal when conducting the fieldwork. Thanks are also due to Erik Meinema for his feedback on earlier drafts.

\section{References}

Alhourani, A. R. (2015) 'Aesthetics of Muslim public and community formations in Cape Town: observations of an anthropologist', Anthropology Southern Africa 38 (1-2): 103-19.

Alhourani, A. R. (2018) 'Aesthetics of Muslim-ness: art and the formation of Muslim identity politics', Journal of Religion in Africa 48 (3): 185-203.

Amin, A. (2012) Land of Strangers. Cambridge: Polity Press.

Bailey, B. (2000) 'Communicative behaviour and conflict between AfricanAmerican customers and Korean immigrant retailers in Los Angeles', Discourse and Society 11 (1): 86-108.

Bjarnesen, J. and M. Utas (2018) 'Introduction. Urban kinship: the micro-politics of proximity and relatedness in African cities', Africa 88 (S1): S1-S11.

Bukasa, P. K. (2018) 'Tactical creolization and the production of belonging in migrant Pentecostal churches in post-apartheid South Africa' in O. Bakewell and L. B. Landau (eds), Forging African Communities: mobility, integration and belonging. London: Palgrave Macmillan.

Buthelezi, M. and D. Skosana (2018) 'The salience of chiefs in postapartheid South Africa: reflections on the Nhlapo Commission' in J. L. Comaroff and J. Comaroff (eds), The Politics of Custom: chiefship, capital, and the state in contemporary Africa. Chicago IL: University of Chicago Press. 
Caton, S. C. (1986) "Salām tahìya": greetings from the highlands of Yemen', American Ethnologist 13 (2): 290-308.

Chari, S. (2014) 'An "Indian commons" in Durban?: Limits to mutuality, or the city to come', Anthropology Southern Africa 37 (3-4): 149-59.

Chari, S. and K. Gillespie (2014) 'Introduction: urban mutualities', Anthropology Southern Africa 37 (3-4): 145-8.

Charway, F. (2019) 'Making citizenship: conflict and co-operation between South Africans and immigrants in the informal economy: the case of the Buffalo City Metropolitan Municipality, Eastern Cape'. PhD thesis, University of Fort Hare. Crush, J. and S. Ramachandran (2015) 'Doing business with xenophobia' in J. Crush, A. Chikanda and C. Skinner (eds), Mean Streets: migration, xenophobia and informality in South Africa. Cape Town: Southern African Migration Programme, African Centre for Cities and International Development Research Centre.

Deeb, L. (2015) 'Thinking piety and the everyday together: a response to Fadil and Fernando', Hau 5 (2): 93-6.

Desai, A. and G. Vahed (2011) 'Between apartheid and neoliberalism in Durban's Indian Quarter', Capitalism Nature Socialism 22 (4): 43-9.

Dlamini, S. N. (2005) Youth and Identity Politics in South Africa, 1990-1994. Toronto: Toronto University Press.

Dube, G. (2017) 'Levels of othering: the case of Zimbabwean migrants in South Africa', Nationalism and Ethnic Politics 23 (4): 391-412.

Elyachar, J. (2011) 'The political economy of movement and gesture in Cairo', Journal of the Royal Anthropological Institute 17 (1): 82-99.

Fourchard, L. and A. Segatti (2015) 'Introduction. Of xenophobia and citizenship: the everyday politics of exclusion and inclusion in Africa', Africa 85 (1): $2-12$.

Garbin, D. (2012) 'Introduction: believing in the city', Culture and Religion 13 (4): 401-4.

Gillespie, K. (2014) 'Murder and the whole city', Anthropology Southern Africa 37 (3-4): 203-12.

Goffman, E. (1963) Stigma: notes on the management of spoiled identity. Englewood Cliffs NJ: Prentice-Hall.

Goffman, E. (1971) Relations in Public: microstudies of the public order. New York NY: Basic Books.

Handler, R. (2009) 'Erving Goffman and the gestural dynamics of modern selfhood', Past and Present 203 (S4): 280-300.

Hankela, E. (2020) 'Segmented urban space and the ethics of belonging in migrants' Johannesburg', Ethnic and Racial Studies 43 (6): 931-49.

Hansen, T. B. and O. Verkaaik (2009) 'Introduction. Urban charisma: on everyday mythologies in the city', Critique of Anthropology 29 (1): 5-26.

Harries, P. (1993) 'Imagery, symbolism and tradition in a South African Bantustan: Mangosuthu Buthelezi, Inkatha, and Zulu history', History and Theory 32 (4): 105-25.

Hentschel, C. (2014) 'The infrastructural passions of urban mutuality', Anthropology Southern Africa 37 (3-4): 161-73.

Jeppie, S. (2007) Language, Identity, Modernity: the Arabic Study Circle of Durban. Cape Town: Human Sciences Research Council Press. 
Kaarsholm, P. (2011) 'Transnational Islam and public sphere dynamics in KwaZulu-Natal: rethinking South Africa's place in the Indian Ocean world', Africa 81 (1): 108-31.

Kaarsholm, P. (2012) 'Diaspora or transnational citizens?: Indian Ocean networks and changing multiculturalisms in South Africa', Social Dynamics 38 (3): 454-66.

Katsaura, O. (2018) 'Ritualistic urbanism: habitualism, mutualism and multinational coexistence in Johannesburg', African Identities 16 (1): 3-17.

Kirby, B. (2017) 'Occupying the global city: spatial politics and spiritual warfare among African Pentecostals in Hong Kong' in D. Garbin and A. Strhan (eds), Religion and the Global City. London: Bloomsbury.

Kirby, B. (2020) 'Flags and shields: Muslim socialities and informal livelihoods in Dar es Salaam', City and Society 32 (3): 556-78.

Kruger, L. (2013) Imagining the Edgy City: writing, performing, and building Johannesburg. Oxford: Oxford University Press.

Kumar, P. P. (2019) 'Grey Street Casbah: market town as a symbol of Indian diasporic existence', Journal of Asian and African Studies 54 (2): 155-68.

Landau, L. B. (2009) 'Living within and beyond Johannesburg: exclusion, religion, and emerging forms of being', African Studies 68 (2): 197-214.

Landau, L. B. (2011) 'Introducing the demons' in L. B. Landau (ed.), Exorcising the Demons Within: xenophobia, violence and statecraft in contemporary South Africa. Tokyo, New York NY and Paris: United Nations University Press.

Landau, L. B. (2019) 'What's behind the deadly violence in South Africa?', New York Times, 16 September <https:/www.nytimes.com/2019/09/16/opinion/ south-africa-xenophobia-attacks.html>, accessed 25 May 2020.

Larkin, B. (2016) 'Entangled religions: response to J. D. Y. Peel', Africa 86 (4): 633-9.

Masquelier, A. (2019) Fada: boredom and belonging in Niger. Chicago IL: University of Chicago Press.

M'Charek, A. (2013) 'Beyond fact or fiction: on the materiality of race in practice', Cultural Anthropology 28 (3): 420-42.

Monson, T. (2015) 'Everyday politics and collective mobilization against foreigners in a South African shack settlement', Africa 85 (1): 131-53.

Moreillon, O. (2019) Reading the Post-apartheid City: Durbanite and Capetonian literary topographies in selected texts beyond 2000. Berlin: Logos Verlag.

Morgan, K. L. (2015) “"What would they do if you greeted?": The potentiality of greetings in the new South Africa', African Studies 74 (1): 123-45.

Mottiar, S. (2019) 'Everyday forms of resistance and claim making in Durban, South Africa', Journal of Political Power 12 (2): 276-92.

Neocosmos, M. (2010) From 'Foreign Natives' to 'Native Foreigners': explaining xenophobia in post-apartheid South Africa: citizenship and nationalism, identity and politics. Dakar: Council for the Development of Social Science Research in Africa (CODESRIA).

Pahlen, B. and L. Stiebel (2017) 'Revisiting Grey Street: the Grey Street writers trail in the context of urban regeneration', Alternation 24 (1): 197-32.

Piper, L. (2003) 'Nationalism without a nation: the rise and fall of Zulu nationalism in South Africa's transition to democracy, 1975-99', Nations and Nationalism 8 (1): 73-94. 
Ramaphosa, C. (2019) 'No man is born a rapist, a woman-batterer or a murderer'. Speech given at South African National Assembly, Cape Town, 18 September $<$ https://www.politicsweb.co.za/documents/no-man-is-born-a-rapist-a-womanbatterer-or-a-murde>, accessed 25 May 2020.

Rosenberg, L. G. (2012) 'A city within a city: vestiges of the socio-spatial imprint of colonial and apartheid Durban, from the 1870s to 1980s'. MA thesis, University of KwaZulu-Natal.

Rudwick, S. I. (2006) 'Language, identity and ethnicity in post-apartheid South Africa: the Umlazi township community'. PhD thesis, University of KwaZuluNatal.

Sadouni, S. (2014) 'Playing global: the religious adaptations of Indian and Somali Muslims to racial hierarchies and discrimination in South Africa', Global Networks 14 (3): 383-400.

Sadouni, S. (2019) Muslims in Southern Africa: Johannesburg's Somali diaspora. London: Palgrave Macmillan.

Sanders, M. (2016) Learning Zulu: a secret history of language in South Africa. Princeton NJ: Princeton University Press.

Sharma, S., S. Reimer-Kirkham and M. Cochrane (2009) 'Practicing the awareness of embodiment in qualitative health research: methodological questions', Qualitative Health Research 19 (11): 1642-50.

Sharma, T. (2016) 'Memory, nostalgia and reality: a socio-historical perspective of the Grey Street Complex'. MA thesis, University of KwaZulu-Natal.

Sheridan, D. (2018) "If you greet them, they ignore you": Chinese migrants, (refused) greetings, and the inter-personal ethics of global inequality in Tanzania', Anthropological Quarterly 91 (1): 237-66.

Sibanda, O. and F. Sibanda (2014) "Land of opportunity and despair": Zimbabwean migrants in Johannesburg', Journal of Social Development in Africa 29 (1): 55-84.

Simone, A. (2014) 'Religiously urban and faith in the city: reflections on the movements of the youth in Central Africa and Southeast Asia' in J. Becker, K. Klingan, S. Lanz and K. Wildner (eds), Global Prayers: contemporary manifestations of the religious in the city. Zurich: Lars Müller.

Siziba, G. (2016) 'The body as a site for (un)making the "other": Shona speaking migrants' negotiation of identity politics in Johannesburg', Journal of Immigrant and Refugee Studies 14 (2): 121-40.

Soske, J. (2017) Internal Frontiers: African nationalism and the Indian diaspora in twentieth-century South Africa. Athens OH: Ohio University Press.

Stanford, K. L. (2011) 'Keepin' it real in hip hop politics: a political perspective of Tupac Shakur', Journal of Black Studies 42 (1): 3-22.

Tella, O. (2016) 'Understanding xenophobia in South Africa: the individual, the state and the international system', Insight on Africa 8 (2): 142-58.

Teppo, A. (2015) 'Introduction: moral communities in African cities', Anthropology Southern Africa 38 (3-4): 284-9.

Vawda, S. (2017) 'Migration and Muslim identities: Malawians and Senegalese Muslims in Durban, South Africa', Journal for the Study of Religion 30 (2): 32-74.

Vinckel, S. (2015) 'Violence and everyday interactions between Katangese and Kasaians: memory and elections in two Katanga cities', Africa 85 (1): 78-102. 


\begin{abstract}
This article explores the everyday lives that African migrants in Durban, South Africa share with other residents of the city. In conversation with Obvious Katsaura's work on 'ethno-mutualism', we use the example of ordinary greeting practices to show how Durban's urban everyday has been hijacked by xenophobic sensibilities. By demonstrating how the act of excluding migrants from these practices threatens to render the quotidian city uninhabitable for them, we shed light on the importance of mundane forms of social interaction for building a sense of identity and belonging. We then consider several ways in which African migrants develop and participate in Muslim forms of sociality that assist them in 'disarming' the urban everyday: from providing a platform for building solidarity with fellow migrants to mediating a 'sense of welcome' from the established Indian South African community. Elaborating on this, we delineate how forms of reciprocity emerge through the interactions between migrant and Indian Muslims that reproduce the ambient life of the city as a shared habitat, opening up new possibilities for entanglement. As such, our analysis contributes to emerging conversations about urban mutuality and migrant religious practices in the everyday lives of African cities.
\end{abstract}

\title{
Résumé
}

Cet article explore la vie quotidienne que les migrants africains partagent à Durban avec d'autres résidents. En dialogue avec les travaux d'Obvious Katsaura sur «l'ethno-mutualisme », les auteurs utilisent l'exemple des pratiques de salutation ordinaires pour montrer comment les sensibilités xénophobes se sont ingérées dans le quotidien urbain à Durban. En démontrant comment l'acte d'exclure les migrants de ces pratiques menace de leur rendre la ville quotidienne inhabitable, les auteurs apportent des éclairages sur l'importance des formes banales d'interaction sociale dans la construction d'un sentiment d'identité et d'appartenance. Ils examinent ensuite plusieurs manières dont les migrants africains développent et participent à des formes musulmanes de socialité qui les aident à " désarmer » le quotidien urbain : de la mise en place d'une plateforme pour construire de la solidarité avec d'autres migrants, à la médiation d'un « sentiment de bienvenue » de la part de la communauté sud-africaine indienne établie. Les auteurs développent ensuite en démontrant comment les formes de réciprocité qui émergent à travers les interactions entre musulmans migrants et indiens reproduisent la vie ambiante de la ville en tant qu'habitat partagé, ouvrant ainsi des horizons inattendus d'intrication mutuelle. En tant que telle, cette analyse contribue aux conversations émergentes sur la mutualité urbaine et les pratiques religieuses des migrants dans la vie quotidienne des villes africaines. 